\title{
Prospective interepisodal mood monitoring in patients with affective disorders: a feasibility study [Corrigendum]
}

Van der Watt ASJ, Suryapranata APSP, Seedat S. Neuropsychiatr Dis Treat. 2018;14:517-524.

On page 518, "Introduction" section, left hand column, the sentence "In particular, there is evidence to demonstrate that the use of weekly correspondence using the Altman Self-Rating Mania Scale (ASRM) and Quick Inventory of Depressive Symptomatology (QIDS-SR 16) may be a useful adjunct to treatment for patients with bipolar disorder. ${ }^{10}$ " should read "In particular, there is evidence to demonstrate that the use of weekly correspondence using the Altman Self-Rating Mania Scale (ASRM) ${ }^{25}$ and Quick Inventory of Depressive Symptomatology (QIDS-SR 16) may be a useful adjunct to treatment for patients with bipolar disorder. ${ }^{10 "}$
On page 519, "ASRM" section, left hand column, the sentence "The ASRM is a five-item self-report questionnaire measuring mania-related symptoms." should read "The ASRM ${ }^{25}$ is a five-item self-report questionnaire measuring mania-related symptoms."

On page 524, "References" list, an additional reference 25 should be added after reference 24 .

Altman EG, HedekerD, Peterson JL, Davis JM. The Altman selfrating mania scale. Biol Psychiatry. 1997;42(10):948-955.
Neuropsychiatric Disease and Treatment

\section{Publish your work in this journal}

Neuropsychiatric Disease and Treatment is an international, peerreviewed journal of clinical therapeutics and pharmacology focusing on concise rapid reporting of clinical or pre-clinical studies on a range of neuropsychiatric and neurological disorders. This journal is indexed on PubMed Central, the 'PsycINFO' database and CAS,

\section{Dovepress}

and is the official journal of The International Neuropsychiatric Association (INA). The manuscript management system is completely online and includes a very quick and fair peer-review system, which is all easy to use. Visit http://www.dovepress.com/testimonials.php to read real quotes from published authors. 